Rzewuska Anna, Żybowska Monika, Sielwanowska Wiktoria, Syzdoł Bartlomiej, Woźniak Magdalena. Complicated acute appendicitis in SARS-Cov-2 infected child. Journal of Education, Health and Sport. 2022;12(2):169-173. eISSN 2391-8306. DOI http://dx.doi.org/10.12775/JEHS.2022.12.02.019

https://apcz.umk.pl/JEHS/article/view/JEHS.2022.12.02.019

https://zenodo.org/record/6189963

The journal has had 40 points in Ministry of Education and Science of Poland parametric evaluation. Annex to the announcement of the Minister of Education and Science of December 21, 2021. No. 32343. Has a Journal's Unique Identifier: 201159. Scientific disciplines assigned: Physical Culture Sciences (Field of Medical sciences and health sciences); Health Sciences (Field of Medical Sciences and Health Sciences).

Punkty Ministerialne z 2019 - aktualny rok 40 punktów. Zalącznik do komunikatu Ministra Edukacji i Nauki z dnia 21 grudnia 2021 r. Lp. 32343. Posiada Unikatowy Identyfikator Czasopisma: 201159. Przypisane dyscypliny naukowe:Nauki o kulturze fizycznej (Dziedzina nauk medycznych i nauk o zdrowiu); Nauki o zdrowiu (Dziedzina nauk medycznych i nauk o zdrowiu).

(1) The Authors 2022;

This article is published with open access at Licensee Open Journal Systems of Nicolaus Copernicus University in Torun, Poland

Open Access. This article is distributed under the terms of the Creative Commons Attribution Noncommercial License which permits any noncommercial use, distribution, and reproduction in any medium, provided the original author (s) and source are credited. This is an open access article licensed under the terms of the Creative Commons Attribution Non commercial license Share alike.

(http://creativecomons or /licenses/by-a a The authors declare that there is no conflict of interests regarding the publication of this paper.

Received: 02.02.2022. Revised: 20.02.2022. Accepted: 20.02.2022.

\title{
Complicated acute appendicitis in SARS-Cov-2 infected child
}

\author{
Anna Rzewuska \\ Uniwersytet Medyczny w Lublinie \\ https://orcid.org/0000-0003-4553-0825 \\ Monika Żybowska \\ Uniwersytet Medyczny w Lublinie \\ https://orcid.org/0000-0002-3885-5907 \\ Wiktoria Sielwanowska \\ Uniwersytet Medyczny w Lublinie \\ https://orcid.org/0000-0002-4660-5027 \\ Bartlomiej Syzdol \\ Uniwersytet Medyczny w Lublinie \\ https://orcid.org/0000-0001-5940-7399 \\ Magdalena Woźniak \\ Uniwersytet Medyczny w Lublinie \\ https://orcid.org/0000-0001-7436-2432
}

Keywords: acute appendicitis, SARS-Cov-2, child

\section{Abstract}

Background:

Appendicitis represents the most common abdominal surgical emergency in children. It is characterized by peri-umbilical pain with migration of the pain to the right iliac fossa, nausea and fever. Recently, an association between acute appendicitis and paediatric inflammatory multisystem syndrome associated with SARS-CoV-2 was suspected.

Case report:

A 15 year old boy was admitted to surgical clinic due to abdominal pain. Laboratory testing revealed high leukocytosis and neutrophilia. The diagnosis was gangrenous, perforated appendicitis with cecal infiltration. Laparoscopic appendectomy was performed with antibiotic prophylaxis and peritoneal lavage. Two days later, a physical examination revealed 
costovertebral angle tenderness bilaterally. Urolithiasis was suspected. X-ray examination revealed no shadows in the projection of urinary system and fluid in the right pleural cavity. Then patient developed a fever and dyspnea. A thoracocentesis was performed and about 500 $\mathrm{ml}$ of transudate was evacuated again. SARS-CoV-2 was detected in the nasopharyngeal swab RT-PCR. Pleural fluid culture was negative. In the following days about $500 \mathrm{ml}$ of fluid from the pleural cavity was evacuated. In laboratory testing was observed an increase in inflammatory markers. The antibiotic therapy was changed and anticoagulant treatment started. Ultrasonography examinations diagnosed abscess at operated area, which involuted after a few days. The male stopped developing fever, the markers of inflammation gradually decreased and respiratory symptoms were not reported.

Conclusions:

Analyzing presented clinical report, it can be concluded that COVID-19 infection prolonged the patient's hospitalization and could have contributed to the complications after appendectomy. The patient's presentations may suggest multisystem inflammatory syndrome potentially associated with COVID-19. Further studies are urgently needed to define the real impact on children health. It may be worth conducting tests for SARS-CoV-2 on children with severe symptoms from the digestive system.

Appendicitis represents the most common abdominal surgical emergency in children. It is characterized by peri-umbilical pain with migration of the pain to the right iliac fossa,nausea and fever [1].Recently, an association between acute appendicitis and pediatric inflammatory multisystem syndrome associated with SARS-CoV-2 was suspected[2].This new disease entity is associated with a fever above $38,5^{\circ} \mathrm{C}$, elevated inflammatory markers, respiratory symptoms, abdominal pain and COVID-19 infection [3].Respiratory symptoms are most common, however, gastrointestinal symptoms are reported too [4]. The clinical spectrum in children is still unclear [5].

Case report:

A 15-year-old boy was admitted to surgical clinic due to abdominal pain occurring for several days. In the right iliac fossa, the ultrasound (US) examination revealed the appendix with two appendoliths. Laboratory tests showed high leukocytosis (20.08 thousand/ul, 3.5-10.5 normal range), neutrophilia (16.47 thousand/ul, 2.5-7 normal range), CRP levels of $12.06 \mathrm{mg} / \mathrm{dl}$ (00.5 normal range), PCT levels of $0.177 \mathrm{ng} / \mathrm{ml}(<0.5 \mathrm{ng} / \mathrm{ml}$ : no systemic infection). The diagnosis was gangrenous, perforated appendicitis with cecal infiltration. Laparoscopic appendectomy was performed with antibiotic prophylaxis and peritoneal lavage. Two days later, physicalexamination revealed positive costovertebral angle tenderness bilaterally.Urolithiasis was suspected. X-ray examination revealed no shadows in the 
projection of urinary system and fluid in the right pleural cavity. Then, the patient began reporting pain in the right hypochondrium. Due to the occurrence of fever above $38^{\circ} \mathrm{C}$ and dyspnoea, a standing chest $\mathrm{X}$-ray was taken once again. It showed progression of fluid accumulation in the right pleural cavity. There was opacity in the lower right lung field and right costophrenic angle with partial blurring of the cardiac silhouette. The fluid was also partially present in the interlobular fissure. The visible lung parenchyma had no detectable infiltrative lesions and the left costophrenic angle was free of lesions. At Th6-7 level, pleural coat was $33 \mathrm{~mm}$ thick. An ultrasound examination revealed the signs of heterogeneous fluid in the right pleural cavity with a thickness of approximately $25 \mathrm{~mm}$ at the base of the lung and at approx. $30 \mathrm{~mm}$ thickness peripherally. Thickened bowel loops with peri-loop hyperechoic reaction were visible in the operated region. Leukocytosis of $15.23,000 / \mathrm{ul}$ and PCT levels of $1.39 \mathrm{ng} / \mathrm{ml}$ were still observed in laboratory tests. There was a significant increase in CRP levels to 29.62 $\mathrm{mg} / \mathrm{dL}$. The following day, a thoracocentesis was performed and about $500 \mathrm{ml}$ of transudate was evacuated. The X-ray taken in the supine position differed from the previous X-ray image in the thickening of the pleural coat, at $73 \mathrm{~mm}$ thickness parabasally. Additionally, an ultrasound examination of the pleural cavities was performed in sitting position. There was a large amount of fluid in the right pleural cavity the pleural coat located in the posterior part of the pleural cavity was 44-48 mm thick (AP dimension, measured below the inferior angle of the scapula). The fluid was visible from the pleural posterior recess to the level of the spine of the scapula. The signs of the right lung parenchyma atelectasis were also present, and the left pleural cavity remained free of fluid. A positive PCR test result for SARS-Cov-2 was also received that day. Pleural effusion cultures were performed; they were negative. Over the next two days, approximately $500 \mathrm{ml}$ of pleural fluid was evacuated again. An increase in CRP levels was still observed in laboratory tests.

Procalcitonin levels started to decline. Saturation (Sp02) during passive oxygen therapy was 91-91\%. The antibiotic therapy was changed and anticoagulant treatment started. A bedside chest X-ray at incomplete inspiration was also taken. The pleural effusion was visible partial opacity of the lower lobe of the right lung and the right costophrenic angle with partial blurring of the cardiac silhouette. The measurement of the pleural coat thickness was impossible due to supine position. Regression in the lesions was observed compared to the previous X-ray image. There where densities within the lower field of the right lung and a slight decrease in the left lung aeration in the lower lobe. The lung parenchyma remained 
without detectable infiltrative lesions and the left costophrenic angle was slightly blurred. In the right iliac fossa, the ultrasound examination revealed a well-circumscribed region measuring 8x11x $5 \mathrm{~cm}$ with signs of a slight flow in Color Doppler imaging, which was consistent with a forming abscess with a small amount of fluid around it. On the following day, a bedside ultrasound was performed once again. An enlarging abscess was observed, extending from the level of the right iliac fossa to the edge of the liver. Gas bubbles were present within the abscess; vascular flow signals were seen at the periphery of the lesion. Moreover, the above-mentioned fluid region was compressed under compression force of an ultrasound transducer. The ascending colon adjacent to the lesion showed signs of oedema. Over the next three days, another bedside ultrasound depicted pleural cavities free of fluid. A homogeneously echogenic fluid region measuring 37x18x56 mm was consistently visible on the abdominal examination. One week later, the PCR test for SARS-Cov-2 was repeated. The patient was still COVID-positive, however, ultrasound examination showed involution of the abscess, which measured 20x8x38 mm. The male stopped developing fever, the markers of inflammation gradually decreased and respiratory symptoms were not reported. Laparotomy wounds healed properly. Three days later, the patient was discharged home.

\section{Conclusions:}

Analyzing presented clinical report, it can be concluded that COVID-19 infection prolonged the patient's hospitalization and could have contributed to the complications after appendectomy. The patient's presentations may suggest multisystem inflammatory syndrome potentially associated with COVID-19. Further studies are urgently needed to define the real impact on children health. Testing for SARS-CoV-2 in children with severe gastrointestinal symptoms should also be considered. Such approach would help prevent further transmission of the virus on the hospital ward and would facilitate patient management.

\section{References:}

1. Lissauer T, Clayden G. Pediatria. Wrocław: Elsevier Urban \& Partner; 2019. 272273.Polish

2. Malhotra, Amisha MD*; Sturgill, Marc PharmD†; Whitley-Williams, Patricia MD*; Lee,

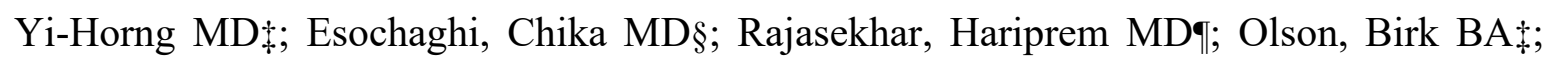
Gaur, Sunanda MD* Pediatric COVID-19 and Appendicitis: A Gut Reaction to SARS- 
CoV-2?, The Pediatric Infectious Disease Journal: February 2021 - Volume 40 - Issue 2 - p e49-e55 doi: 10.1097/INF.0000000000002998

3. Royal College of Paediatrics and Child Health: Guidance: Paediatric multisystem inflammatory syndrome temporally associated with COVID-19. 2020.

4. Tian Y, Rong L, Nian W, He Y. Review article: gastrointestinal features in COVID-19 and the possibility of faecal transmission. Aliment Pharmacol Ther. 2020;51(9):843-851. doi:10.1111/apt.15731

5. Lee, Pui Y et al. "Distinct clinical and immunological features of SARS-CoV-2-induced multisystem inflammatory syndrome in children." The Journal of clinical investigation vol. 130,11 (2020): 5942-5950. doi:10.1172/JCI141113 